\title{
Evaluation of the influence of malocclusion in interpersonal relations among adolescents
}

Avaliação da influência da má oclusão nas relações interpessoais entre os adolescentes

Ana de Lourdes Sá de LIRA ${ }^{1}$, Francisco Dário Carvalho de SOUSA ${ }^{1}$

1 - Universidade Estadual do Piauí - UESPI - School of Dentistry - Department of Pediatric Dentistry and Orthodontics - Area of Integrated Clinic - Parnaíba - PI - Brazil.

\begin{abstract}
Aim: To evaluate the influence of malocclusion on interpersonal relationships among adolescents. Method: A cross-sectional, quantitative study was carried out with 360 students. Photographs of male and female mouth with malocclusions were manipulated and superimposed on the smile images of two individuals of both genders with normal occlusion (corresponding to the control group, GC) respectively, for assembly of 4 malocclusions: (1) anterior open bite, (2) anterior crossbite (3) dental crowding, and (4) Class II, in this order. These images were provided to the participants, who evaluated them through a questionnaire. Results: The less attractive malocclusion was dental crowding. For both flirting and maintaining a serious relationship the previous open bite was the most rejected, with Class II being the most acceptable. Conclusion: For adolescents, dental crowding is the most appropriate malocclusion to be corrected orthodontically. Malocclusions negatively influence the development of interpersonal relationships among adolescents.
\end{abstract}

\section{KEYWORDS}

Adolescent; Malocclusion; Interpersonal relationships.

\section{RESUMO}

Objetivo: Avaliar a influência da maloclusão nas relações interpessoais entre os adolescentes. Método: Um estudo transversal, quantitativo foi realizado com 360 estudantes. Fotografias de bocas masculina e feminina com maloclusões foram manipuladas e superpostas nas fotos do sorriso de duas pessoas de ambos os gêneros com oclusão normal (correspondendo ao grupo controle, GC) respetivamente, para montagem de 4 maloclusões: (1) mordida aberta anterior, (2) mordida cruzada anterior (3) apinhamento dos incisivos superiores, e (4) Classe II, nesta ordem. Essas imagens foram fornecidas aos participantes, que as avaliaram por meio de questionário. Resultados: A maloclusão menos atrativa foi o apinhamento dentário. Tanto para flertar como para manter um relacionamento sério a mordida aberta anterior foi a mais rejeitada, sendo a Classe II a mais aceitável. Conclusão: Para os adolescentes o apinhamento dentário é a maloclusão mais indicada a ser corrigida ortodonticamente. As maloclusões influenciam negativamente no desenvolvimento das relações interpessoais entre os adolescentes.

\section{PALAVRAS-CHAVE}

Adolescente; Maloclusão; Relações Interpessoais. 


\section{INTRODUCTION}

$\mathrm{M}$ alocclusion, defined as a change in growth and development affecting tooth occlusion, is considered a public health problem, since it presents a high prevalence and can negatively interfere in the quality of life, impairing the social interaction and the psychological wellbeing of individuals affected $[1,2,3]$.

It presents multifactorial origin, hardly being attributed a single specific cause. It can be caused by general factors such as: congenital, hereditary, nutritional deficiencies or by local factors such as: supernumerary teeth, dental caries and early loss of deciduous teeth [4].

The assessment of occlusion considering public health aspects aims to determine the need and priority of treatment and to obtain information to adequately plan the resources needed to provide orthodontic treatment to the population $[3,5]$.

Most of the articles studied in the age group of 12 to 17 years showed that malocclusion in permanent dentition causes impact on quality of life, since adolescents with malocclusion without orthodontic treatment were more likely to have physical, psychological and social impacts $[6,7]$. In this context, the main factors influencing the decision for orthodontic treatment from the patient's point of view are: dissatisfaction with facial appearance, dentist's recommendation, parental concern and influence of school colleagues using orthodontic appliance $[8,9,10]$.

At the beginning of adolescence, school, community and friends groups influence personal behaviors and values during the period of self-esteem formation [11].

In this way, those with any malocclusion will probably face difficulties in acceptance and social interaction due to aesthetic reasons. In more severe cases, they result in functional and emotional limitations, especially during adolescence, a phase in which social and affective interactions are more intense [12,13].

Malocclusion may present physical, psychological and social effects in individuals.
It affects the smile, fundamental part of the facial appearance and the expression of the emotions [14]. Dental aesthetics have a direct effect on quality of life, mainly related to social acceptance $[3,15,16]$.

Based on this context the objective of this research was to investigate if the malocclusions interfere in the interpersonal relations between the adolescents.

\section{METHOD}

This was a cross-sectional and quantitative study carried out after the approval of the Research Ethics Committee of the State Universality of Piauí-CEP / UESPI, opinion number: 65108317.1.0000.5209.

The sample calculation was based on the target population: teenagers from the city of Parnaíba, attending high school in 13 state public schools, choosen by lot, in 2017 , totaling 6.240 students. The sample size calculation was based on the target audience: adolescent students from the city of Parnaíba, PI, attending high school in public schools in 2017. Thus, in order to successfully achieve the objective of the present study, it was based on the survey by the Brazilian Institute of Geography and Statistics, which estimates an estimated 15.000 people in the target population: adolescents living in the city of Parnaíba-Pi aged 15 to 18 years. From this, the sample size formula was performed, resulting in a number of 365 , but 5 did not want to participate in the study.

This minimum number of participants is considered sufficient considering the proposed analyzes, the 5\% sampling error, and $95 \%$ confidence level, indicating that the probability of the mistake made by the research does not exceed 5\% [17].

The tests were applied with 360 high school students, with 120 students for each series (1st, 2nd and 3rd years), corresponding to 60 male students and 60 female students.

The inclusion criteria were adolescents who were attending high school in state 
schools, who accepted to participate in the study. Students were randomly chosen by lot. As an exclusion criterion, students who did not attend high school in those schools, those who were unable to understand and respond to the questionnaires, such as those with cognitive deficits, syndromes or hearing impairment, visual or those who did not wish to participate in the research.

The study had as its principle the ethical foundation and the norms contained in Res. $\mathrm{N}^{\mathrm{O}} 466 / 12$ (CNS / MS), with the signing of the Term of Free and Informed Consent (TFIC) by the parents or guardians, as well as the Term of Free Assent and Clarified (TFAC) by the young people involved in the research.

First, two photographs of the face with a smile showing the teeth with normal occlusion of a young man(Figure 1) and the other of a young girl (Figure 2), aged 18 years, were used as a group control (CG), obtained with digital camera (Canon model EOS 450 D).

Oral photographs of both genders with malocclusions were digitally manipulated by the Adobe Photoshop program (Adobe, San Jose, Calif., Inc.) and superimposed on the CG smile photos respectively for the assembly of 4 malocclusions: (1) anterior open bite (2) anterior crossbite (3) anterior dental crowding and (4) Class II, in this order. The modifications were only dental in the CG so that the faces remained unchanged. Eight images of these 4 malocclusions were obtained, 4 images of male mouths and 4 images of female mouths, which were superimposed on the smile images of the two young men who served as CG, respectively.

The sample was divided equally for better comparison between genders. For the male participants, the female images were presented, both the manipulated images, corresponding to the four malocclusions and the CG. Similarly, for female students, male images were presented, both manipulated and CG images.

Then the test was applied with 5 questions: (1) At a party, does a person with this kind of smile attract you? (2) Would you start an intentional conversation with a person with this kind of smile? (3) Would you flirt with a person with this kind of smile? (4) Would you start a lasting relationship with a person with this smile? (5) Would you suggest orthodontic treatment to make the smile more harmonious?

They responded the test using the Likert scale, which had five options: "I fully agree" (certain about the answer - with a score of 5 points), "I agree partially" (I'm not sure - 4 point) , "I completely disagree", (showing negative certainty - with a value of 1 point), "I partially disagree" (partial negative certainty, doubt - with a value of 2 points) and "I do not agree or disagree" (the teenager interviewed did not express opinion on the subject - with a value of 3 points) (Figure 3 ).

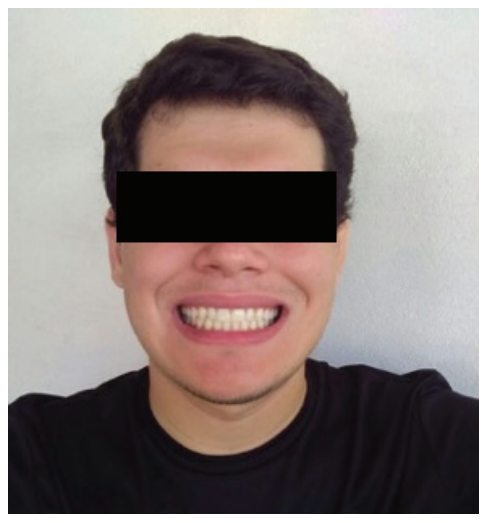

Figure 1 - Photograph of the face with a smile showing the teeth with normal occlusion of a young man.

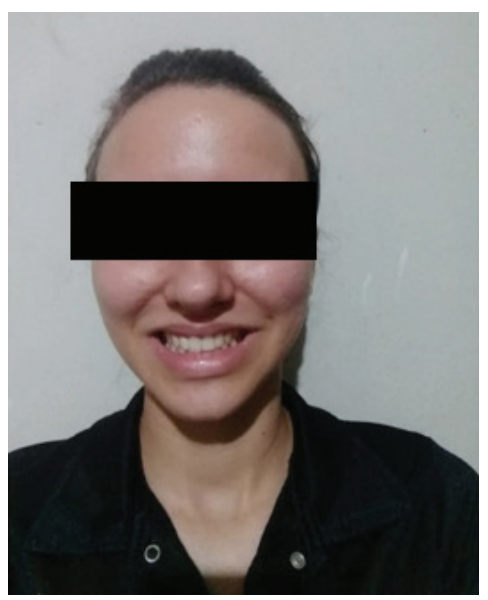

Figure 2 - Photograph of the face with a smile showing the teeth with normal occlusion of a young girl. 


\section{QUIZ}

1) At a party, does a person with this kind of smile attract you?

1 - ( ) I strongly agree 2 - ( ) I partially agree 3 - ( ) I disagree Completely 4 - ( ) I disagree partially

5-( ) I do not agree or disagree

2) Would you start an intentional conversation with a person with this kind of smile?

1 - ( ) I strongly agree 2 - ( ) I partially agree 3 - ( ) I disagree Completely 4 - ( ) I disagree partially

5-( ) I do not agree or disagree

3) Would you flirt with a person with this kind of smile?

1 - ( ) I strongly agree 2 - ( ) I partially agree 3 - ( ) I disagree Completely 4 - ( ) I disagree partially

$$
\text { 5-( ) I do not agree or disagree }
$$

4) Would you start a lasting relationship with a person with this smile?

1 - ( ) I strongly agree 2 - ( ) I partially agree 3 - ( ) I disagree Completely 4 - ( ) I disagree partially

$$
\text { 5-( ) I do not agree or disagree }
$$

5) Would you suggest orthodontic treatment to make the smile more harmonious?

1 - ( ) I strongly agree 2 - ( ) I partially agree 3 - ( ) I disagree Completely 4 - ( ) I disagree partially

5-( ) I do not agree or disagree

Figure 3 - Questionnaire used in the survey, according to the Likert scale.

The two researchers were previously calibrated at the Clinical School of Dentistry (CSD) of the State University of Piauí, to determine the time of visualization of the images and the level of difficulty of the interview. For calibration, we used oral images with the smile of 20 adolescents with malocclusions and 4 images of normal occlusion [18].

Subsequently, the pilot study involving 45 students who did not participate in the research was carried out with the objective of testing the proposed methodology. As a result, their viability was observed, without adjustments. In order to assess intra- and inter-examiner reproducibility, $10 \%$ of the total sample was examined twice by each of the examiners, with the Kappa coefficient for inter and intra-examiner agreement being 0.79 and 0.85 , respectively.

The rules for the analysis of the photographs and answers to the questionnaire were previously explained, so that there would be no doubts.

The photos were displayed on the 14inch computer placed at a distance of $30 \mathrm{~cm}$ from the evaluator, and they were altered by 
the computer program Adobe Photoshop 7.0. Each photograph was individually exposed on a Power Point slide page.

Then the CG image was visualized for 1 minute, and the questionnaire was answered within 2 minutes at most without displaying the image again. Subsequently, the images of the malocclusions were evaluated in this order: anterior open bite, anterior crossbite, anterior dental crowding and Class II, with no right to return to the previous image, totaling 15 minutes for each participant ( 3 minutes for visualization of each image and corresponding to the CG interview and the four malocclusions of the research), totaling 5 images and 5 questionnaires for each research participant [19]. The order of presentation of the images was determined by lot.

Using the statistical package in version 21 , from the results of the descriptive analysis of the means, followed by the Chi-square test with repeated measures, we observed which images interfered in the interpersonal relations, specifically, attraction, intentional conversation, flirtation, relationship serious and suggestive for the beginning of an orthodontic treatment.

\section{RESULTS}

The average age of the sample was 16.7 ( \pm 1.3). In Table 1 , the means of the responses according to the Likert scale and application of the Chi-square test were presented with respect to the interest according to the type of smile.

Regarding all the questions that were applied, there were significant differences ( $p$ $<$.001) between the CG photos (with normal occlusion) and the malocclusion photos. All malocclusions had a negative impact on the individuals' acceptance for relationship purposes when compared to the CG image.
Table 1 - Averages and standard deviation of the answers of the questions based on the occlusions analyzed and $\mathrm{P}$ value (Chi-square test)

\begin{tabular}{|c|c|c|c|c|c|c|}
\hline Questions & $\begin{array}{l}\text { CG } \\
(\mathbf{s d})\end{array}$ & $\begin{array}{c}\text { Anterior } \\
\text { open } \\
\text { bite } \\
\text { (sd) }\end{array}$ & $\begin{array}{l}\text { Anterior } \\
\text { crossbite } \\
\text { (sd) }\end{array}$ & $\begin{array}{l}\text { Anterior } \\
\text { dental } \\
\text { crowding } \\
\text { (sd) }\end{array}$ & $\begin{array}{c}\text { Class } \\
\text { II } \\
\text { (sd) }\end{array}$ & $\begin{array}{c}P \\
\text { Value }\end{array}$ \\
\hline Attraction & $\begin{array}{c}3.84 \\
( \pm 0.5)\end{array}$ & $\begin{array}{c}3.84 \\
( \pm 0.5)\end{array}$ & $\begin{array}{c}2.71 \\
( \pm 0.4)\end{array}$ & $\begin{array}{l}2.69 \\
( \pm 0.6)\end{array}$ & $\begin{array}{c}2.94 \\
( \pm 0.3)\end{array}$ & $<.001$ \\
\hline $\begin{array}{l}\text { Intentional } \\
\text { conversation }\end{array}$ & $\begin{array}{c}3.79 \\
( \pm 0.7)\end{array}$ & $\begin{array}{c}2.93 \\
( \pm 0.6)\end{array}$ & $\begin{array}{l}2.88 \\
( \pm 0.5)\end{array}$ & $\begin{array}{c}2.82 \\
( \pm 0.4)\end{array}$ & $\begin{array}{c}2.97 \\
( \pm 0.7)\end{array}$ & $<.001$ \\
\hline Flirt & $\begin{array}{c}3.68 \\
( \pm 0.5)\end{array}$ & $\begin{array}{c}2.66 \\
( \pm 0.8)\end{array}$ & $\begin{array}{l}2.77 \\
( \pm 0.4)\end{array}$ & $\begin{array}{l}2.75 \\
( \pm 0.6)\end{array}$ & $\begin{array}{c}2.87 \\
( \pm 0.7)\end{array}$ & $<.001$ \\
\hline $\begin{array}{l}\text { Lasting } \\
\text { relationship }\end{array}$ & $\begin{array}{c}3.61 \\
( \pm 0.7)\end{array}$ & $\begin{array}{l}2.63 \\
( \pm 0.5)\end{array}$ & $\begin{array}{c}2.72 \\
( \pm 0.4)\end{array}$ & $\begin{array}{l}2.69 \\
( \pm 0.6)\end{array}$ & $\begin{array}{c}2.74 \\
( \pm 0.8)\end{array}$ & $<.001$ \\
\hline Treatment & $\begin{array}{l}3.35 \\
( \pm 0.5)\end{array}$ & $\begin{array}{c}3.72 \\
( \pm 0.6)\end{array}$ & $\begin{array}{l}3.77 \\
( \pm 0.4)\end{array}$ & $\begin{array}{c}3.87 \\
( \pm 0.6)\end{array}$ & $\begin{array}{c}3.77 \\
( \pm 0.7)\end{array}$ & $<.001$ \\
\hline
\end{tabular}

\section{DISCUSSION}

According to the literature, there is a strong relationship between physical appearance and social attractiveness. The concept "what is beautiful is good" makes attractive people obtain social benefits attributable to their appearance, due to the existence of physical stereotypes [20]. Generally, individuals with attractive physical and / or facial characteristics cause positive expectation and impression, gaining advantages in interpersonal relations [21].

The present study corroborated the findings of Pithon et al. [19] and Beall [22] when affirming that among the types of malocclusions, the dental crowding was what most reduced the attractiveness of the smile (Figure 4). According to a research on the differences in attractiveness comparing modifications of the female profile of Class II malocclusion by Yüksel et al. [23], the image of a woman with a Class II profile was judged to be significantly less attractive.

In this study, the adolescents answered preferred to maintain an intentional conversation with CG and people with Class II malocclusion (Figure 5), probably because they find this malocclusion more attractive than the others. In the study by Pithon et al. [24] they stated that individuals with Class II malocclusion are more sociable after undergoing orthognathic surgery. 


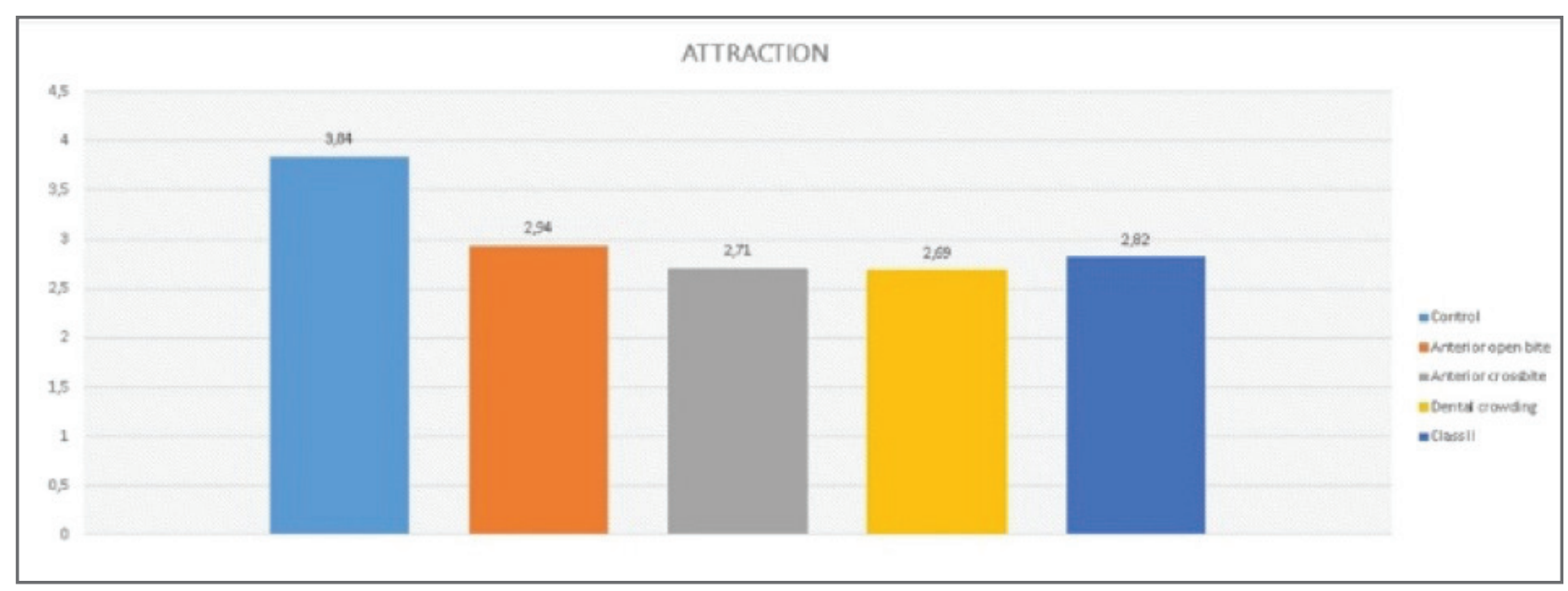

Figure 4 - Smile attractiveness analysis graph, according to the Likert scale.

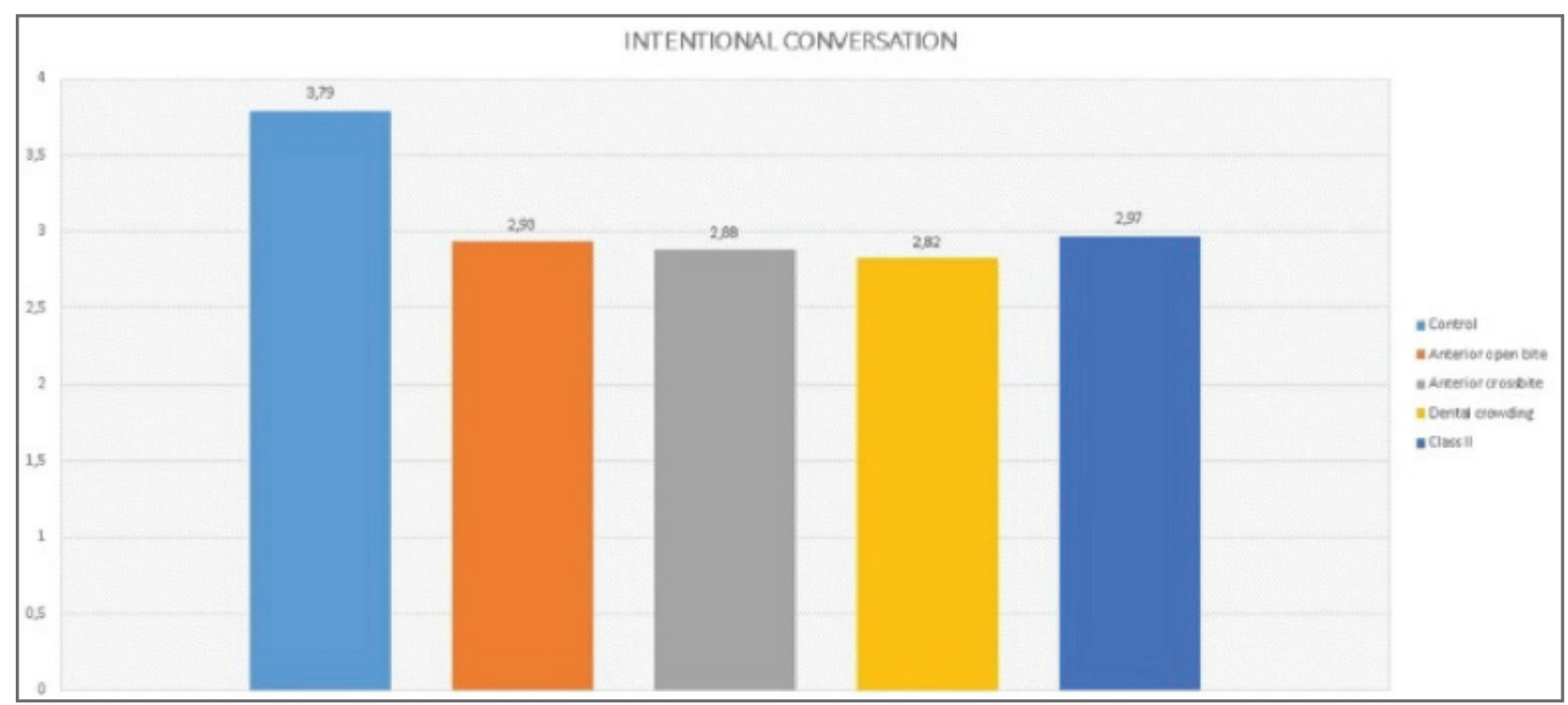

Figure $\mathbf{5}$ - Graph of the groups evaluated in relation to the average of the answers on the subject intentional conversation, according to the Likert scale.

This work demonstrated that both to flirt and to maintain a lasting relationship the adolescents preferred those who presented Class II malocclusion, being the most attractive, when compared to the other malocclusions analysed (Figures 6 and 7). However, in Beall's research [22], this malocclusion has a strong impact on the perception of facial attractiveness, with straight facial profiles being considered more attractive than those with mandibular retrusion combined with maxillary protrusion. Naini et al. [25] also found that Class II patients had significantly reduced attractiveness ratings and had a greater desire for orthognathic surgery.

The authors observed that both to flirt and to maintain a lasting relationship the image of person with open bite aroused less interest on the part of the adolescent (Figures 6 and 7). Similar situation had also been observed by Scapini et al. [12], Claudino et al. [13], and Ocampo-Parra et al. [26] 
who evidenced that in the presence of this malocclusion, people have difficulty initiating, maintaining and closing a conversation in an effective way. Such situation would facilitate the development of lasting relationships, as well as being necessary in several everyday interpersonal contexts.

The anterior dental crowding was the type of malocclusion, whose adolescents involved in the research would most likely suggest the orthodontic treatment (Figure 8), corroborating the research by Pithon et al. [19], who found that although malocclusions have a negative impact on the individuals' acceptance, when a lasting relationship was initiated, dental crowding was the malocclusion that would most motivate them to suggest the orthodontic treatment. This finding had also been reported by Oliveira and Sheiham [3], emphasizing the strong concern of teenagers with the alignment of their teeth.

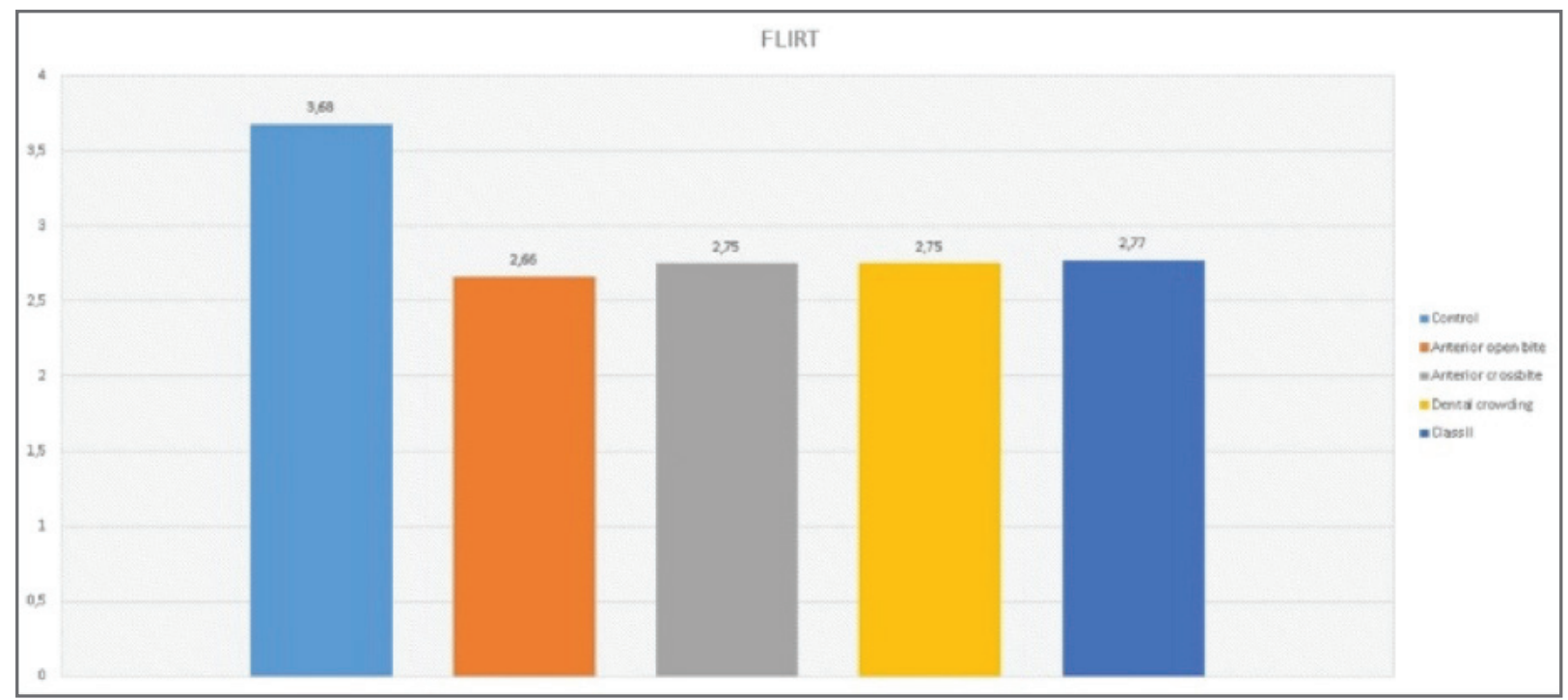

Figure 6 - Graph of the groups evaluated in relation to the average of the responses on the flirting item, according to the Likert scale.

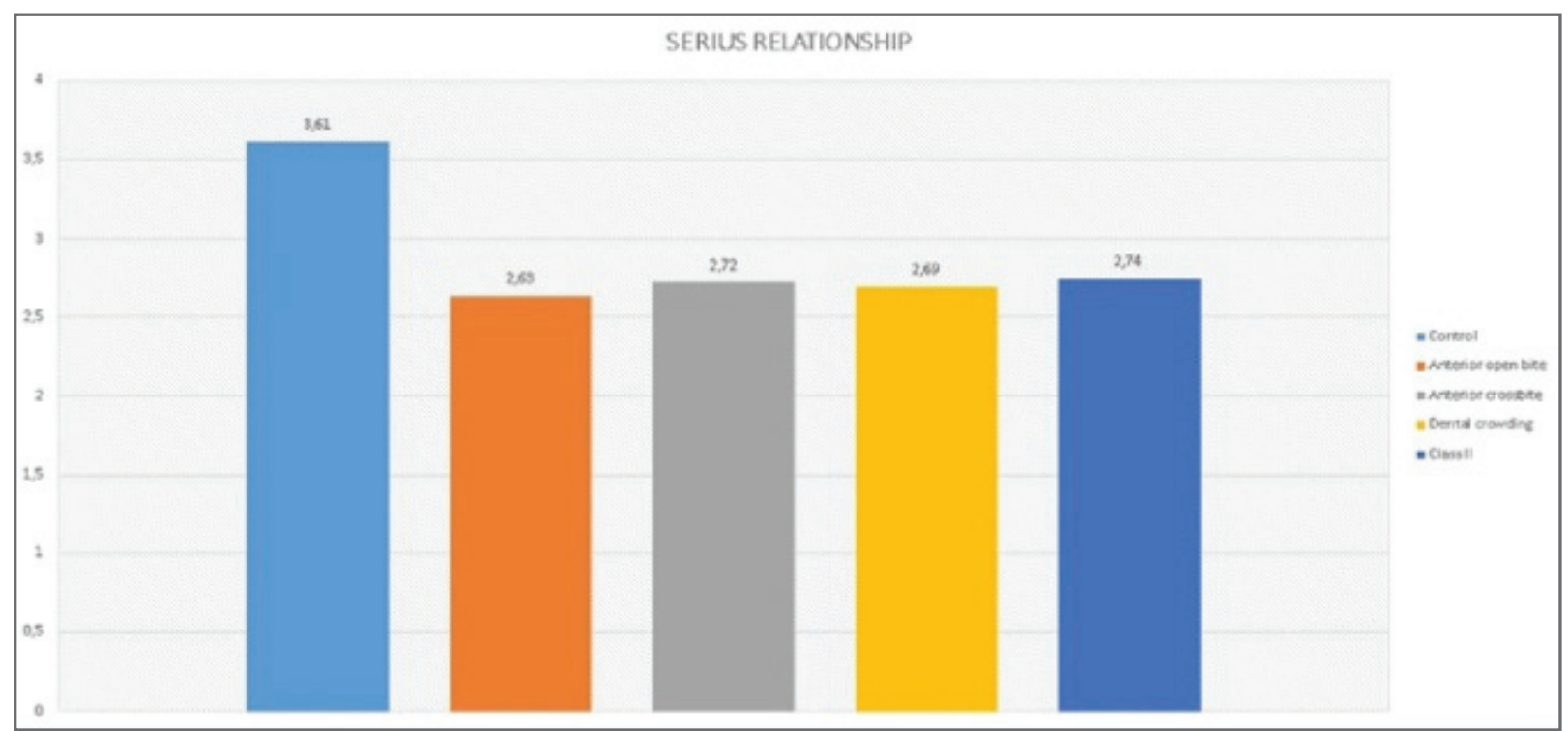

Figure 7 - Graph of the groups evaluated in relation to the average of the answers on the issue of serious relationship, according to the Likert scale. 


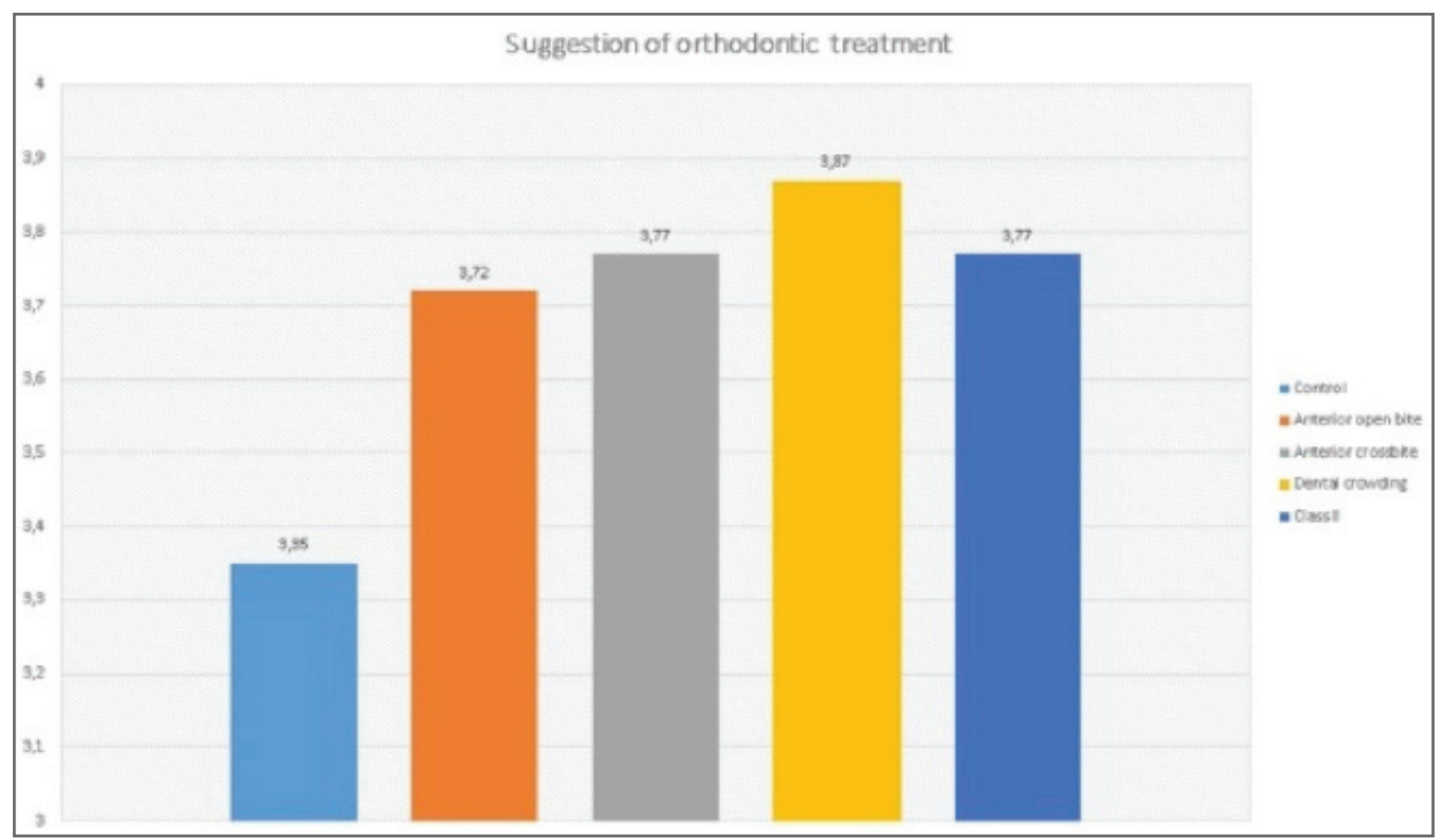

Figure 8 - Graph of the groups evaluated in relation to the average of the answers on the suggestion of orthodontic treatment, according to the Likert scale.

This research elucidated that malocclusions negatively influence the development of relationships among teenagers, since individuals with good occlusion are more accepted from the perspective of affective life. Pithon et al. [27] have shown that facial appearance plays an important role in judging personal attractiveness and also in developing self-esteem, overcoming even functional issues. Including Oliveira et al. [28] in a review study on occlusal issues, they observed that oral alterations had a reportedly negative impact on the quality of life of adolescents.

\section{CONCLUSION}

People with anterior dental crowding aroused less attration among adolescents, who participated in this research.

To maintain an intentional conversation, the adolescents in the study prefer people with Class II malocclusion.
For both flirting and maintaining a serious relationship the previous open bite was the most rejected, with Class II being the most acceptable.

For adolescents, dental crowding is the most appropriate malocclusion to be corrected orthodontically.

Malocclusions negatively influence the development of interpersonal relationships among adolescents.

\section{REFERENCES}

1. Moimaz SAS, Rocha NB, Garbin AJl, Saliba O. A influência da prática do aleitamento materno na aquisição de hábitos de sucção não nutritivose prevenção de oclusopatias. Rev Odontol UNESP.2013;42(1):31-6. doi:10.1590/ S1807-25772013000100006.

2. Sotto KLZP,Hely HC, Mallmann FH, Abegg C. Need for orthodontic treatment in adolescents from the state of Rio Grande do Sul, Brazil: association between self-perception and clinical need. RF0.2018 May-Aug;;23(2):86-92. doi:10.5335/ rfo.v23i28345.

3. Oliveira CM, Sheiham A. Orthodontic treatment and its impact on oral healthrelated quality of life in Brazilian adolescents. J Orthod. 2004 Mar; 31(1):20-7. doi:10.1179/146531204225011364. 
4. YuX, Liu B, Pei Y,Xu T. Evaluation of facial attractiveness for patients with malocclusion: a machine-learning technique employing Procrustes. Angle Orthod 2014;84:410-6. doi: 10.2319/071513-5161.

5. Dias PF,Gleiser R. The index of need for orthodontic treatment as a method of evaluation in public health. Dental Press Ortodon Ortop Facial. 2008 Jan/ Febr;13(1):74-81.

6. Martins-Júnior PA, Marques LS, Ramos-Jorge ML. Malocclusion social, functional and emotional influence on children. J Clin Pediatr Dent. 2012 Fall;37(1):103-8. doi:10.17796/jcpd.37.1.y75430328427210j.

7. BernabéE, Tsakos G,Messias de Oliveira C, Sheiham A. Impacts on daily performances attributed to malocclusions using the condition-specific feature of the Oral Impacts on Daily Performances Index. Angle Orthod. $2008 \mathrm{Mar}$; 78(2):241-7. do::10.2319/030307-1111.

8. Bos A, Hoogstraten J, Prahl-Andersen B. Expectations of treatment and satisfaction with dentofacial appearance in orthodontic patients. Am J Orthod Orthop Dentofacial. 2003; 123(2):127-32. doi: 10.1067/mod.2003.84.

9. Marques LS, Ramos-Jorge ML, Paiva SM, Pordeus IA. Malocclusion: aesthetic impact and quality of life in Brazilian schoolchildren. Am J Orthod Orthop Dentofacial. 2006; 129(3): 424-7. doi: 10.1016/j.ajodo.2005.11.003.

10. Baca-Garcia A, Bravo M, Baca A, Junco P.Maloclusions and orthodontic treatment needs in a group of Spanish adoles centes using the dental aesthetic index.IntDent J. 2004:54(3):138-42.

11. Campos FL, VazquezFL, Cortellazzi KL, Guerra LM, Ambrosano GMB, Meneghim MC. The malocclusion and its association with socioeconomic variables, habits and care with five years old children. Rev Odontol UNESP.2013 May-June; 42(3):160-6.

12. Scapini A, Feldens CA, Ardenghi TM, Kramer PF. Malocclusion impacts adolescents' oral health-related quality of life. Angle Orthod. 2013 May; 83(3):512-8. doi: 10.2319/062012-5091

13. Claudino D, TraebertJ. Malocclusion, dental aesthetic self-perception and quality of life in a 18 to 21 year-old population: a cross section study. BMC Oral Health. 2013 Jan;13(3):1-6. doi:10.1186/1472-6831-13-3.

14. Van Der Geld P, Oosterveld P, Van Heck G, Kuijpers-Jagtman AM. Smile attractiveness. Self--perception and influence on personality.2007 Sep; 77(5):759-65. doi: 10.2319/082606-349.

15. TraebertES, Peres MA. Prevalence of malocclusions and their impact on the quality of life of 18-year-old young male adults of Florianopolis, Brazil. Oral Health Prev Dent. 2005;3(4):217-24.

16. Marques LS, Filogonio CA, Filogonio CB, Pereira L J,Pordeus IA, Paiva SM. Aesthetic impact of malocclusion in the daily living of Brazilian adolescents. J Orthod. 2009 Sep;36(3):152-9. doi:10.1179/14653120723139.
17. LuchesaCJ, Chaves Neto A. Cálculo do tamanho da amostra nas pesquisas em administração. Curitiba: Edição do autor,2011.27p.

18. Peres MA, Traebert J,Marcenes W. Calibration of examiners for dental caries epidemiology studies. Cad Saúde Pública. 2001jan-feb;17(1):153-59.

19. Pithon MM, Santos CR, Santos NL, Lima SOAS, Coqueiro RS, Santos R L. Impact of malocclusion on affective / romantic relationships among young adults. The Angle Orthodontist. 2016 July; 86(4):638-43. doi. org/10.2319/030915-146.1.

20. Henson ST, Lindauer SJ,Gardner WG, Shroff B, Tufekci E. Best A.M. Influence of dental aesthetics on the social perception of adolescents judged by pairs. Am J Orthod. 2011September; 140(3):389-395. doi:10.1016/j.ajodo.2010.07.026.

21. Levin L,Meshulam-Derazon S, Hauben DJ, Ad-EID. Selfreported smile satisfaction: smile parameters and ethnic origin among Israeli male young adults. NY State Dent J. 2007;73(5):48-51.

22. Beall AE.Can a new smile make you look more inteligente and successful? Dent Clin North Am. 2007;51(2):289-97.

23. YükseL AG, Iskender SY, KuitertR, Papadopoulou AK, Dalci K, Darendeliler MA, Dalci 0. Differences in attractiveness comparing female profile modifications of Class II Division 1 malocclusion. Am J Orthod Dent Orthop. 2017 0ct;152(4):471-6. doi: 10.1016/j.ajodo.2017.01.025.

24. Pithon MM, RochaMFN, Da SilvaCR, De Andrade ACDV. Impact of orthognathic correction of Class II malocclusion on the perception of social characteristics. Turk J Orthod. 2017 Sep;30(3):69-72 doi:10.5152/ TurkJOrthod.2017.16024.

25. Naini FB, Donaldson AN, Mcdonald F, Cobourne MT. Assessing the influence of lower facial profile convexity on perceived attractiveness in the orthognathic patient, clinician, and layperson. Oral Surg Oral Med Oral Pathol Oral Radiol. 2012Sept; 114(3):303-11. doi:10.1016/j.tripleo.2011.07.031.

26. Ocampo-ParraU,Escobar TB, Serra AV, RuedaZV,Lema MC. Prevalence of dyslexia in schoolchildren aged 8 to 16 years with anterior open bite in the city of Envigado, Colombia. BMC Oral Health. 2015 July;15(1):77. doi:10.1186/ s12903-015-0063-1

27. Pithon MM, Santos AM, Campos MS, Couto FS, dos Santos AF, Coqueiro Rda $\mathrm{S}$, etal. Perception of laypersons and dental professionals and students as regards the aesthetic impact of gingival plastic surgery. Eur J Orthod. 2014;36: 173-178. doi:10.1093/ejo/cit020.

28. Oliveira DC, Pereira PN, Ferreira FM, Paiva SM, Fraiz FC. Reported impact of oral alterations on the quality of life of adolescents: a systematic review. Pesq Bras Odontoped Clin Integr. 2013 Jan/Mar;13(1):123-9. doi:10.4034/PBOCl.2013.131.18.

\section{Ana de Lourdes Sá de Lira} (Corresponding address)

Universidade Estadual do Piauí, Faculdade de Odontologia

Rua Senador Joaquim Pires 2076 Ininga. CEP: 64049-590. Teresina-PI-Brasil

E-mail: anadelourdessl@hotmail.com

Date submitted: 2019 May 26

Accept submission: 2019 0ct 22 